\title{
THE HISTORICAL LAYERS \\ OF THE LOWER SILESIA TOWNS - THE INVESTIGATIONS BASED ON HISTORICAL CARTOGRAPHY
}

\author{
Rafal EYSYMONTT \\ the University of Wrockaw, Institute of Art History; \\ ul. Szewska 36, 50-137 Wroctaw, Poland; \\ e-mail: eysymont@uni.wroc.pl
}

\begin{abstract}
Studies on the historical layers of historical towns belong to the most important stages of Atlas historyczny miast polskich' volumes' creation.

Lower Silesian towns are investigated mainly on a basis of:

- written sources, which reference to the real space is often doubtful;

- archeological explorations, which results should be confronted with source studies;

- metrological studies, claiming the original medieval concepts according to their geometrical modularity, although those studies are often loaded with big doses of idealism;

- studies on historical cartography, which were performed however usually a few hundred years after the town's foundation; in this case the basic method is relating newer plan to an earlier situation called retrogression.
\end{abstract}

The last method could regard one of the most mutable, but most important element of a city's historical structure, which is the river. Two examples of this kind of analysis, referring to two of Lower Silesian different size cities of Wrocław and Milicz can be mentioned in this case. Changes of river system in these cities drastically influenced the shaping of cities and their environment. Much more controversial is an issue of reconstruction based on the oldest $18^{\text {th }}$ century cartography of the road system, which was shaping settlements network around Wrocław. The method of using historical cartography as a source of knowledge about a city's changes is giving the best results in a case of wide modern forti-fications' analysis, though it is often only confirmed by archeological research.

Key words: history of urbanism, cartography, cities development, history of cartography 


\section{INTRODUCTION}

Historical cartography belongs the most important sources of information about changes in urban historical space. Considering the fact that maps and plans presented the real existing space and weren't only propaganda or artistic products, information they contain, which sometimes differs from our view on reality only with method of cartographic presentation, provides the most reliable sketch of historical space. Confrontation of a map or plan with written source gives the fullest view on former city space and forms the basis of retrogression - a reconstruction of historical reality, made also in a form of a map. This was also the method used during the work on Atlas historyczny miast polskich.

\section{METHODS, STUDY AREA}

I will start from information about the most important cartographical relics of Lower Silesia. However, I will talk only about handmade maps, and I will avoid the topic of countless examples of hand-printed maps, issued in greater number for touristic purposes, made in this area since the half of $19^{\text {th }}$ century. One of the oldest of these, a map from 1820 was still produced with a copperplate technique (Grundriss von Breslau, 1820 durch Carl Heinrich Studt. Stiftung Preussischer Kulturbesitz, Geheimes Staatsarchiv Berlin, sign. PK XI. HA Karten E 50 904.).

The plan of Wroclaw made by Friedrich Gross around the year 1580 seems to be the oldest handwritten and at the same time measuring plan regarding Lower Silesian towns. Unfortunately, we know it only from poor reproductions and one hand-drawn copy made for Silesian Province Conservator. A handcopy of the particular plan's sections is kept in Silesian Province Conservator's Files in Herder Institute in Marburg. It shows not only the shapes of building quarters and different width of streets, but also projections of particular buildings between the street network. It reminds of definitely later plans, like the ones from Legnica from the beginning of $18^{\text {th }}$ century.

The $16^{\text {th }}$ and the beginning of $17^{\text {th }}$ century in Silesia weren't too rich in results of urban cartographers' work. Vedutas were much more popular during these times. Few city plans with clear quarters' sketches were made only during the time of fortress' rebuilding, during Thirty Years' War in $17^{\text {th }}$ century. Plans of Głogów, Namysłów, Kłodzko, Brzeg and Oława, stored in State Archive in Vienna provide some examples. Few $17^{\text {th }}$ century plans are also kept in State Archive in Wrocław, some of them were reproduced by Bimler (1940-1942). They contain abundant information regarding quarter's division, but they show mainly the area of modern earth ramparts and slopes of fortress' rings, which later were basis for foundation of municipal park - green belt around the city. Less significant are Valentin Saebisch's $17^{\text {th }}$ century plans, which are being more concepts of fortifications than study on the city (eg plans of Świdnica, Brzeg, Legnica). Most of them were published in Bimler's work (1940-1942) and lately in Atlas historyczny miast polskich (Młynarska-Kaletynowa et al. red. 2009). 
There aren't also too many city plans made before the second half of $18^{\text {th }}$ century, which means from the time before Silesia was adopted by Prussia. One of the most interesting is the plan of Legnica from ca. 1706 (Plan de la ville de Liegnitz, 1706. Österreichische Nationalbibliothek Wien, Kartensammlung, sign. FKB L 16 Kar.) reproduced in Atlas historyczny miast polskich (Młynarska-Kaletynowa et al. red. 2009) and very fine and exact Legnica City plan from ca. 1735 (Plan de la ville et Chateau de Liegnitz en Silesie. Österreichische Nationalbibliothek Wien, Kartensammlung, sign. FKB F 7/6) reproduced in the atlas mentioned above. For Wrocław, the most important of early cartographically mapped plans (Plan der Stadt und Vestung Breslau de Hohendorf, Österreichisches Staatsarchiv, Wien, Kriegsarchiv, sign. G Ic 75) has to be dated about 1709-1729 the other one was made in year 1717 (Geometrischer Grund-Riss und Delineation der Haupt-Statt und Vestung Bresslau in Herzogthum Ober und Nieder Schlesien mit allen seinen Vorstätten und nahe anliegenden Dörffen wurde im Jahre 1717 im Frühjahr mit Boussole aufgenommen und observiret von Daniel Pezold. Stiftung Preussischer Kulturbesitz, Staatsbibliothek Berlin, Kartenabteilung, sign. x/s 20 644). Both were reproduced in Atlas historyczny miast polskich (Młynarska-Kaletynowa \& Eysymontt red. 2001).

Many of the plans were made during the period of Silesian Wars and Seven Years' War (1741-1762). Some of them include the exact comment describing the fortress, like the plan of Legnica from year 1757 (Österreichisches Staatsarchiv, Wien, G I c 329-03) published in Atlas historyczny miast polskich (Młynarska-Kaletynowa et al. red. 2009). These plans were made by the military officers of both Prussian and Austrian forces. These were, how it might appear after measure scale, mainly plans made for military measurement purposes and often their distinctive feature was inverted orientation with north down on a map. It refers to many plans of Wrocław as well (Młynarska-Kaletynowa \& Eysymontt red. 2001; comment to historical cartography, 31-34). These plans were also used for sketching all the changes in fortress arrangement until the time it was demolished. However, the town of Świdnica has the biggest collection of its own plans from the period of Silesian Wars and just until the fortress demolition after 1865. Catalogue of Świdnica's historical cartography, based on plans stored in Wrocław Archive, State Library in Berlin-Dahlem, State Library in Berlin, State Archive in Wrocław, State Library in Vienna and cartographical collection of Archive Militaire de Vincennes L'Armee Aerien et de 1, Armee de Terre in Paris is over 250 positions, but not all have been published in historical atlas of the city (Eysymontt 2008: 5-15).

Many of eighteenth-century plans, besides presenting their basic topic of fortifications, are so exact, that they let reconstruct and recall the shape of quarters subdivision, building projections shape and placement of most important buildings.

Cartographical material, which occurred in the middle of $18^{\text {th }}$ century, being the first cartographic representations of new areas of the Prussian state display notable change in amount and quality. This material was made that time by new Prussian government, following introduction of new building laws on this area. In case of cities' plans it resulted from highly intensive rebuilding in most of little town areas due to new rigorous fire regulations, 
which forced reconstructing the buildings' shapes, requiring gable switch from perpendicular to parallel orientation to the street. It sometimes strongly changed the structure of whole town's plots' division (Eysymontt 1998, 2000: 69-80, 2001: 188-189, 2002a: 164, 2002b: 73-83, 2004: 222). The plan of Świebodzice from year 1774 (Eysymontt J. \& Eysymontt R. 2001: 188) provides an example of plan illustrating those changes.

The unique drawings of Środa Śląska and Wałbrzych from 1771 (Situations Plan von dem Ringe der Stadt Neumarkts. Von Gross?, Bauinspector. National Archive in Wrocław, sign.: Kartografia Rejencji Wrocławskiej IV/227) or plan of Wałbrzych from 1737 (Situations Plan Der statd Waldenburg nebst umherliehgenden Grenzen wie Solche Anno 1736 und 1737 von Tit. Herrn Friedrich Gottlieg Schulz Kayserlichen Ingenieur Lieutenant und Geometra vermessen und aufgenomen. Copiert Ao 1777 Herder Institute in Marburg, sign. 03348 ) serve also as examples of more exact $18^{\text {th }}$ century plans. Some $18^{\text {th }}$ century plans of the city's fortress, additionally depicting precisely the city, considering even former subdivision were also preserved. This sort of plan was made for example for Świdnica (Plan of Świdnica with fortifications, 1762, Staatsbibliothek zu Berlin - Preussischer Kulturbesitz, Berlin, sign. Kart. x 33650 - Bl. 3). From the later period of more exact plans, cadastral maps are preserved. The most valuable of them are the plans of Legnica. First of them was made by surveyor Isemer in 1777 (Johann Friedrich Isemer is listed in Schlesische Instanzions Notizen as Municipal Building Inspector in Legnica in 1770 and 1775), and is better known from redrawing from 1812, or currently from Kurt Bimler's copy. Still, two other cadastral plans of Legnica are preserved. One was made in 1826, scaled 1:45 000 (Kuhlmey 1826) another in 1825, scaled 1:10 000 (Kuhlmey 1825). On the other hand, there is category of more "sketchy" plans, not preceded by exact measurements, where the whole series of "bird's eye views" and simplified city plans included in Friedrich Werner's "Topography" belong. Some of them, like the plan of Strzelin are quite simplified (Wernher 1756). Another plan, of the town of Brzeg, shows the town area in perspective abbreviation and contains the most important buildings' shapes (Wernher 1765: 128).

City plans contain also maps made in much less precise scale (Katalog 1901, Hanke Degner 1935). Information about them includes the catalog of the exhibition in Berlin. Exhibition took place from 7 II till 4 IV 1987 times. Catalogue was prepared by Klaus Lindner with collaboration of Lothara Zögner (Lindner \& Zögner 1987). Most important Polish study is book of Wytyczak (1998). Work of Czechowicz (2004) is based mainly on cartographical collection in National Museum in Wrocław.

Basic available cartographical research material, showing many cities in the second half of eighteenth century are plans included in Christian Friedrich Wrede's (1747-1753) atlas referring to left Oder bank's area of Silesia. Sixty-seven plans of Silesian cities placed on Oder left-bank, scaled 1:14 000 were placed on title-pages of this atlas, which is letting us to observe subdivision of cities and towns and placement of towns' most important buildings (about prussian maps: Maschke 1928). Those maps are stored in cartographical collections of Staatsbibliothek in Berlin (sign. Kart N 15 060). Plans contained wide belt of the land, from Oława to Głogów (Lindner 1985). 
Prussian lieutenant and engineer Christian Wrede obtained his experience working under the supervision of his father on Kłodzko County's maps. These maps were captured during the Seven Years' War by Austrians and currently are stored in War Archive in Vienna. Many young contributors were helping Wrede during creation of five-volume atlas from years 1747-1753, what helped them later to work alone as celebrated cartographers. Five volumes of this atlas contain hundred-ninety-five maps scaled 1:33 333 (Schlenger 1930; Lindner \& Zögner 1987: 175). First volume covered the area along the Silesian border with Poland from Lusatia till Moravia and contained forty-two maps, second volume contained coverage of current Upper Silesia, part of former Duchy of Opole and Racibórz. During two years (1748/9) forty-five plans were prepared, next year thirty-five plans of left-Oder-bank Upper Silesia, and only in 1751 thirty-six maps of Lower Silesian were made, mainly regarding subsequent Regierungsbezirk Liegnitz from Złotoryja to Nowogrodziec over river Kwisa.

The last of the volumes covered right-Oder-bank Lower Silesia and contained fortytwo maps. Purpose of making those plans becomes more clear, mainly because of statistical data, capturing specifically number of farmers and horses, placed on each town's maps' edges, which could be easily used for possible military conscriptions. This inventory could be considered an introduction to further Zimmerman's registry (Zimmermann 1785-1795). However, big fertile extents placed south of Wrocław weren't considered in this atlas being strategically less important and previously better examined by Frederick The Great's army. As a result, these areas are not shown in this atlas. Wrede's maps were made only for military purposes, which affected their accuracy. Not many copies of them were redrawn. However, the Austrian army still got the majority of secret Prussian maps in possession, along with general Foque's bundle acquired in battle under Kamienna Góra. Since that time Austrian cartography developed impressively. This was manifested by numerous copies redrawn from Prussian maps from the collection of lieutenant Laudon, stored in War Archive in Vienna, and, on the other hand, whole series of Josephinische Landesaufnahme, made for similar purposes like the Wrede's atlas (Schlenger 1938: 17, 18).

Ludwig Wilhelm Regler's maps (Regler, Schlesien 1764-1770 - Staatsbibliothek in Berlin, sign.: Kart N 15 140) also refered to the Wrede's maps. Information about Regler is included in catalogue of Lindner \& Zögner (1987: 176) and also in Maschke (1928: 331-335). The maps, scaled 1:24 000, made in hundred-four sections during years 1764-1777 were even more artistic than Wrede's map and cover left bank of Oder with "freed towns and villages". Only surroundings of fortresses Koźle and Głogów were mapped on the right side of the river. Towns and villages on this map are drawn in more schematic way, even though they are mapped in finer scale. Their reference to Wrede's map is quite clear, partially because of fact that Regler's first cartographical works were made under supervision of Wrede. Unfortunately, 1781's Friedrich Wilhelm Carl von Schmettau's map of whole Silesia was made in less fine scale 1:50 000, so towns' plans placed on this map do not matter that much in their history's studies (Staatsbibliotheek Berlin, Kartenabteilung, sign. Kart L 5420/7). 
Equivalent of Wrede's maps for the area of Silesia, which remained in Austrian hands after Silesian Wars are previously mentioned Josephinisch maps, stored in State Archive in Vienna. Those maps, made in 1763 in forty sections scaled 1:28 800 were revised in 1780. They are carefully drawn and showing not only physiographical elements, but also particular locations with denotation of separate farms. Made with help of mapping table, compass and astrolabe, they cover the area of Silesia from Cieszyn until the border with of Kłodzko County (Map stored in National Archive in Vienna Kriegsarchiv Wien, sign. BIX a 175).

Maps made during the first Prussian topographical measurement - so called Urmestischblatts, made in twenties and thirties of XIX century also provide important scientific material. Still, their scale (1:24 000) lets us only define the main elements of cities' external functional system like roads and rivers, but sometimes they astonishingly exactly shows us parts of city's equipment like mills, windmills or m even earlier forests mentioned in XIII or XIV century (maps stored in Staatsbibliothek zu Berlin, Preussischer Kulturbesitz in Berlin, sign. N 729).

So called "separation plans" born usually in thirties of $19^{\text {th }}$ century provided new impulse for making Silesian towns' and settlements' maps. They were connected with a process of "integration", basically meaning the regrouping of different owners areas. Plans of Brochów made in 1818 or Oporów from 1837, stored currently in State Archive in Wrocław (National Archive, Wrocław, sign. Komisja Generalna Wr 133-Brochów, 1818, wyk. Opitz, kop. 1826 Thoreind, scale 1: 5000, sign. Komisja Generalna Wr. 169-Oporów, 1837 Geissler, 1: 2500) (about them: Szulc 1963) provide good examples of such maps.

The other group of plans are cities' cadastral plans. The oldest are made in twenties of $19^{\text {th }}$ century. I should mention here the plan of Wałbrzych from 1823 , on which not only the exact land subdivision and estate property numeration are marked, but also types of roofing (Archive Berlin-Dahlem, sign. B 50. 286). For most of the towns these are practically the oldest plans, where primary parcelation and numeration of lots were marked. The author of plans considered as well differences in street width and curvature of lot lines, very important for our view on urban areas development stages. In some cases it lets us also define the fragments of layout from the times before town was founded. The functions of particular objects marked on a plan sometimes differ from those kept in industrial era after 1873 and sometimes they let us designate easily the exact location of objects known formerly only from archival references and chronicles.

However, most of these plans made in more exact metric scale 1:1000 or 1:2500 was made only in sixties of XIX century. Cadastral plan of Legnica, preserved in State Archive of Legnica, was made in 1863, cadastral plan of Środa Śląska in 1860 (Środa Ślaska. Cadastral plan, 1860. Situations und Flurkarte von Kreisstadt Neumarkt. Aufgenomen berechnet und kartiert in den Monaten März bis September 1860, D. Staub(?)mann Baumeister. Środa Śląska, 18 August 1860. Museum in Środa Śląska, sign. MŚR 9). Also for Wrocław, the oldest cadastral plan was made only in years 1863-1866. Moritz Sadebeck made it with 
most modern these times geodetic methods in scale 1:1000. Most of this plan's parts are stored in Wrocław University's Library. Unfortunately, cartographer wasn't able to mark all of plot subdivisions of city's historical center. In Ossolineum Library's cartographical collection colorful version of this plan is stored and it shows mainly the city's center (National Ossoliński Institute, Cartography Section, sign. 3810/A Case 26). It was also the base for many forthcoming printed city plans.

Great value is represented by simplified cadastral plans made in one scale, gathered in Files of Conservator of Province of Silesia in Herder's Institute in Marburg. Those plans were made mainly in 1865 by Alkiewicz for towns of: Bolków, Bierutów, Kąty Wrocławskie, Przemków (1875), Głuchołazy, Oława, Jawor, Głogów, Brzeg Dolny, Twardogóra, Ziębice, Świdnica, Świebodzice (1866), Żagań, Gryfów, Strzelin, Nowa Ruda, Oleśnica and Namysłów. Despite notable simplification, especially in rear and yard parts of the buildings plots, those plans should be considered very valuable. Most of them is published in Eysymontt (2009).

The interesting episode of Silesian cartography is represented by maps made in thirties of $20^{\text {th }}$ century along with Third Reich's German State "modernization". As an example we can take plans of Środa Śląska, Trzebnica, Świdnica or Milicz. However, those plans in majority quickly turned out as just an utopian vision, like the road belt around Środa Śląska designed in 1933 and actually built only after Second World War (Neumarkt im Oktober 1933, Arch. Klein. Herder Institut Marburg. Niederschlesisches Bildarchiv, sign. 130. 105. Plan published in Atlas historyczny miast ślaskich, IV: Śląsk, 2: Środa Śląska).

Handwritten plans were made after Second World War as well. Unusual value is represented by plans scaled mainly 1:1000, made after the needs of late fifties' and early sixties' plots of urban rearrangement. Their value also derives from the fact, that they allow us to see the image of the cities just before they turned into prefabricated concrete tower blocks housing estates. Those plans sometimes contain different coloring for each stage and indicates time when particular buildings were built, which additionally makes them even more interesting - see plans 46 and 47 in Atlas historyczny miast polskich (Młynarska-Kaletynowa et al. red. 2009). These plans were made in 1956.

\section{RESULTS (SELECTED EXAMPLES)}

The following examples could show how scientific material described above can be used in reconstruction works:

- Reconstruction of river system of Milicz, based on very destroyed plans made in the end of $18^{\text {th }}$ century, drastically changing our point of view on city development's conditions (Fig. 1). 
- Reconstruction of Wrocław's river system changing our view on city's beginning and rural areas, especially east of the city. Reconstruction works were based on exact hypsometry, cartographical analysis and comparison of various cartographical research materials from various periods of time (Fig. 2).

- Reconstruction of Legnica's cadaster and reconstruction of town's suburbs based on $18^{\text {th }}$ century maps. Maps are showing unnoticed by historians until now importance of innodation areas (strategically flooded areas) known from $18^{\text {th }}$ century description. They show us unstable structure of suburbs as a zone town's defence buffer zone (Fig. 3).

- Reconstruction of fortifications of Wrocław made with use of historical cartography and reconstruction of some streets' shapes, mainly in former suburb areas. Streets were drawn along the border of external Glacis, which shows general conditions of street network development outside the center (Fig. 4).

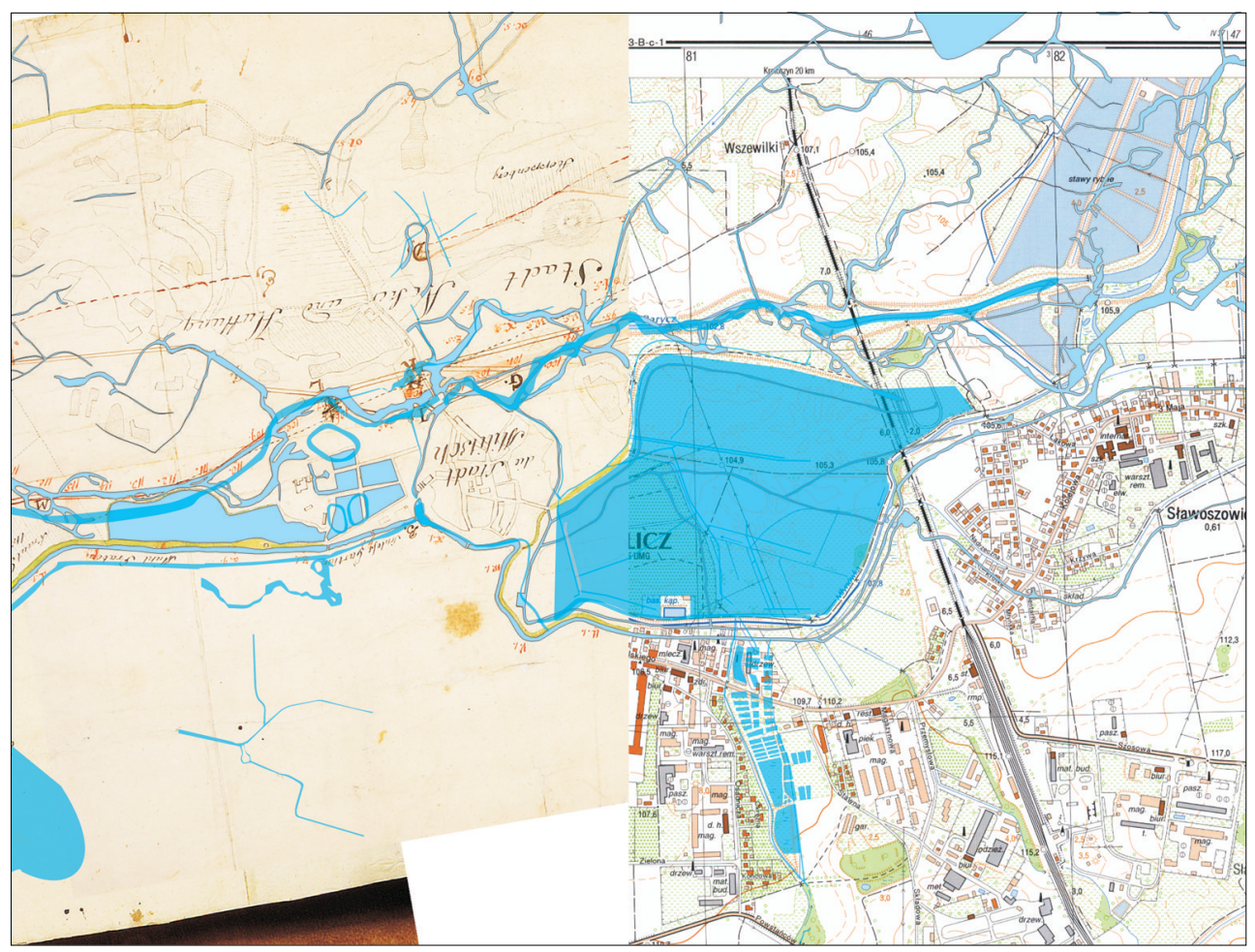

Fig. 1. Milicz. Watercourses and reservoirs around 1750, around 1824 and today.

Drawn on 1750 and 1990's base.

Cartographical edition Marcin Siehankiewicz 


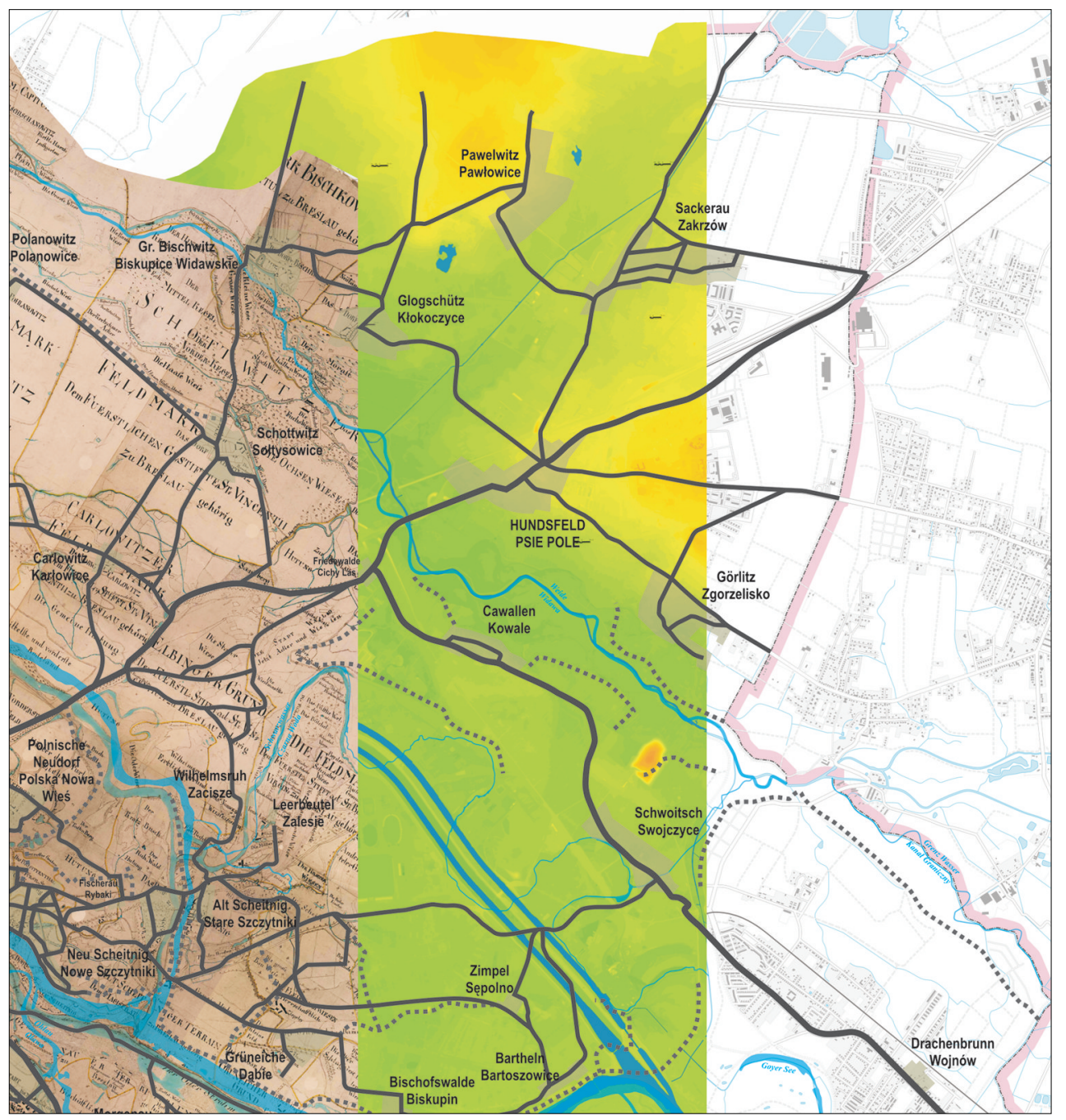

Fig. 2. Fragment of river system's reconstruction in Wrocław. 1794's Klemt's map and modern 2012 review map.

Cartographical edition Marcin Siehankiewicz 


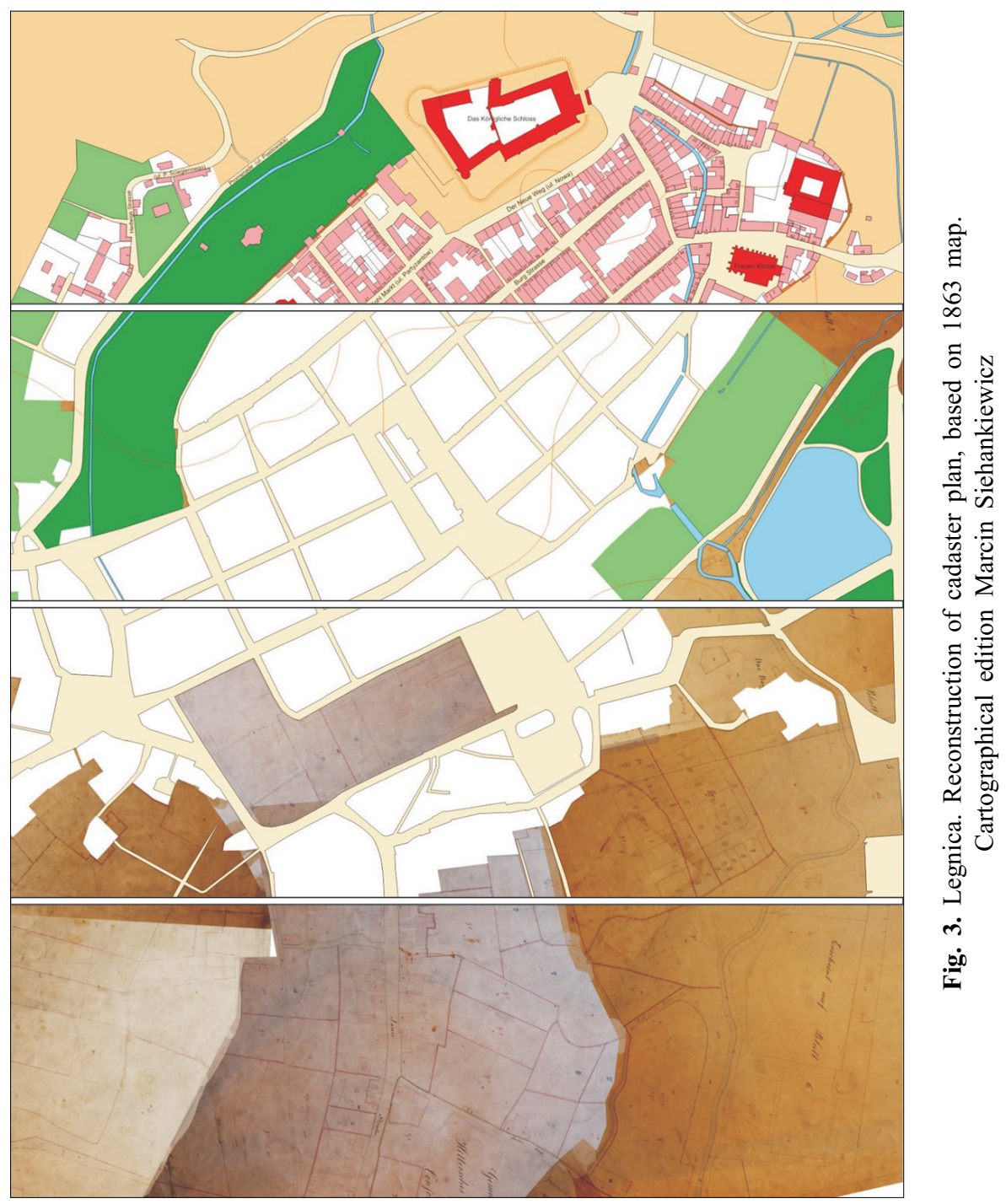




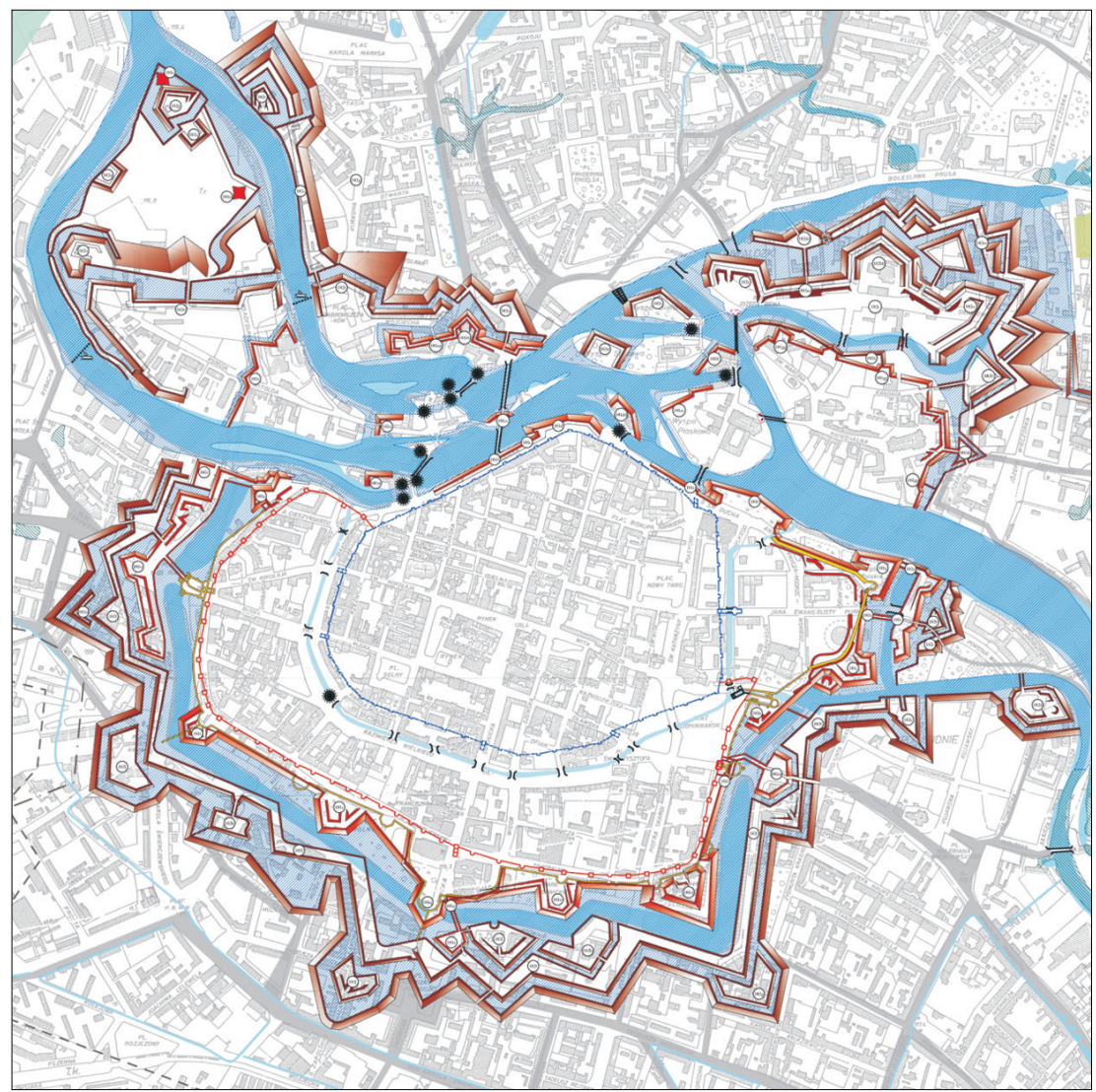

Fig. 4. Reconstruction of Wrocław fortification system since half $13^{\text {th }}$ until the beginning of $19^{\text {th }}$ century. Base - situational-altitude measures map from 1970. Cartographical edition Jarosław Połamarczuk

The most important source for the reconstruction work were mentioned above topographic maps by Christian Friedrich Wrede (1747-1753) and Urmestischblatt (twenties and thirties of $19^{\text {th }}$ century) and other special plans prepared for Milicz, Wroclaw and Legnica. For Milicz it is, for example, the plan of the second half of the eighteenth century, kept in the National Archives in Wroclaw (Odra river board regulations I/185), for Wroclaw plan from 1794 (State Archive in Wrocław, the Odra River board regulations I/131), for Legnica stored at the State Archives Legnica fragments cadastral plan from 1863. All these above mentioned reconstruction fundamentally change our contemporary perspective on these city. Reconstructions performed by superposition of historical information and current topographic map, however, are only a rough picture of the historical space. Nevertheless, it is a serious basis for contemporary planning. 


\section{CONCLUSION}

Historical cartographical scientific materials are not only a source of the information, but also the basic tool used for a process of balanced urban planning, leading to fulfillment of all the life's necessities with no unnecessary harm to the geographical and historical environment.

\section{REFERENCES}

Bimler K., 1940-1942. Die Schlesischen massiven Wehrbauten. Kommission Heydebrand-Verlag, Breslau.

Czechowicz B., 2004. Historia kartografii Ślaska XIII-XIX wieku. Wrocławska Fundacja Studentów Historii Sztuki, Wrocław.

Eysymontt R., 1998a. Architektura i rozwój przestrzenny w XIX i na początku XX wieku. [in:] Dąbrowski S. (red.), Legnica. Zarys monografii miasta, DTSK Silesia, Wrocław, $320-352$.

Eysymontt R., 1998b. Urbanistyka i architektura miasta w okresie baroku. [in:] Dąbrowski S.

(red.), Legnica. Zarys monografii miasta, DTSK Silesia, Wrocław, 214-227.

Eysymontt R., 2000. Barwne projekty z XVIII i początku XIX wieku w archiwum w Legnicy. Architectus, 1, 69-80.

Eysymontt R., 2002a. Rozwój przestrzenny, architektura, sztuka. [in:] Kościk E. (red.), Wołów. Zarys monografii miasta, Silesia, Wrocław - Wołów, 154-198.

Eysymontt R., 2002b, Burgum milickie - przemiana w małe miasto. [in:] Buśko C. (red.), Civitas et villa. Miasto i wieś w średniowiecznej Europie Środkowej, Instytut Archeologii i Etnologii Polskiej Akademii Nauk, Wrocław, 73-83.

Eysymontt R., 2004. Architektura i sztuka. [in:] Matwijowski K. (red.), Oława. Zarys monografii miasta, Silesia, Wrocław, 199-224.

Eysymontt R., 2008. Dzieje Świdnicy w kartografii. Rocznik Świdnicki, 35, 5-15.

Eysymontt R., 2009. Kod genetyczny miasta. Średniowieczne miasta lokacyjne Dolnego Ślaska na tle urbanistyki europejskiej. Via Nova, Wrocław.

Eysymontt J. \& Eysymontt R., 2001. Świebodzice, rozwój przestrzenny, architektura sztuka. [in:] Matwijowski K. (red.), Świebodzice. Zarys monografii miasta, Silesia, Wrocław - Świebodzice, 188-189.

Hanke M. \& Degner H., 1935. Geschichte der amtlichen Kartographie Brandenburg Preussens bis zum Ausgang der Friderizianischen Zeit. Stuttgart.

Katalog der Ausstellung des XIII. Deutschen Geographentages zu Breslau. 1901. Genossenschafts-Buchdruckerei, Breslau.

Kuhlmey J.F., 1825. Plan der Stadt Liegnitz nebst ihren Vorstädten und nächsten Umgebungen Liegnitz bei, Aufgenommen u. gezeichnet vom K. Radierungs Conducteur Stumpe im Jahre 1825. Staatsbibliothek zu Berlin, sign. x 28808. 
Kuhlmey J.F., 1826. Plan der Stadt Liegnitz nebst ihren Hausnummern und öffentliche Gebäuden Aufgenommen und gezeichnet vom K. Regier Conducteur Stumpe, Liegnitz. Staatsbibliothek zu Berlin, sign. x 28812.

Lindner K. \& Zögner L., 1987. Zwischen Oder und Riesengebirge. Schlesischen Karten aus fünf Jahrhunderten. Ausstellung der Staatsbibliothek Preussischer Kulturbesitz, Berlin.

Lindner K., 1985. Wredes "Krieges Carte von Schlesien" - die erste preußische Landesaufnahme Schlesiens. [in:] von Scharfe W. \& Jäger E. (eds), Kartographiehistorisches Colloquium Lüneburg '84, 15.-17. März 1984, Vorträge, Berlin, 39-53.

Maschke T., 1928. Die topographischen Karten (Landesaufnahmen) Schlesiens aus der Zeit Friedrich des Grossen. Zeitschrift des Vereins für Geschichte Schlesiens, 62, Breslau, 331-335.

Młynarska-Kaletynowa M. \& Eysymontt R. (red.), 2001. Atlas historyczny miast polskich. Tom 4: Ślask. Zeszyt 1: Wrocław. Via Nova, Wrocław.

Młynarska-Kaletynowa M., Eysymontt R. \& Goliński M. (red.), 2009. Atlas historyczny miast polskich. Tom 4: Ślask. Zeszyt 9: Legnica. Wydawnictwo Uniwersytetu Wrocławskiego, Wrocław.

Plan of Świdnica with fortifications. 1762. Staatsbibliothek zu Berlin-Preussischer Kulturbesitz, Berlin, sign. Kart. x 33 650-B1. 3.

Schlenger H., 1938. Des grossen Königs Krieskarte. Schlesische Monatshefte, 17, 18.

Schlenger H., 1930. Form ländlicher Siedlungen in Schlesien. Beiträge zur Morphologie der schlesischen Kulturlandschaft. Verlag von M. \& H. Marcus, Breslau.

Situations Plan Der statd Waldenburg nebst umherliehgenden Grenzen wie Solche Anno 1736 und 1737 von Tit. Herrn Friedrich Gottlieg Schulz Kayserlichen Ingenieur Lieutenant und Geometra vermessen und aufgenomen. Copiert Ao 1777. Herder Instytute in Marburg, sign. 03348.

Szulc H., 1963. Osiedla podwrocławskie na poczatku XIX wieku. [in:] Monografie Śląskie Ossolineum, 5, Zakład Narodowy im. Ossolińskich, Wrocław.

Von Gross?, Bauinspector, 1777, Situations Plan von dem Ringe der Stadt Neumarkts. National Archive in Wrocław, sign. Kartografia Rejencji Wrocławskiej IV/227.

Wernher F.B., 1756. Topographia oder Prodromus Delineati Principatus Lignicensis Bregensis, et Volaviensis, 1744-1768 [...]. Volumen IV: Das ist Fürstentum Liegnitz: Liegnitz, Brieg Wohlau Trachenberg. Fürstentum Brieg. von F. B. Wernhero, p. 131, sign. XVII HA Rep. 135 nr 526/4.

Wytyczak R., 1998. Ślask $w$ dawnej kartografii. Obraz Ślaska na mapach XVI-XVIII wieku w zbiorach Zakładu Narodowego im. Ossolińskich we Wrocławiu. Towarzystwo Przyjaciół Ossolineum, Wrocław.

Zimmermann F.A., 1783-1795. Beyträge zur Beschreibung von Schlesien. Bd. 1-12. 